\title{
Impact of treated wastewater irrigation on antibiotic resistance in the soil microbiome
}

\author{
Joao Gatica • Eddie Cytryn
}

Received: 1 December 2012 / Accepted: 17 January 2013 /Published online: 2 February 2013

(C) The Author(s) 2013. This article is published with open access at Springerlink.com

\begin{abstract}
The reuse of treated wastewater (TWW) for irrigation is a practical solution for overcoming water scarcity, especially in arid and semiarid regions of the world. However, there are several potential environmental and health-related risks associated with this practice. One such risk stems from the fact that TWW irrigation may increase antibiotic resistance (AR) levels in soil bacteria, potentially contributing to the global propagation of clinical AR. Wastewater treatment plant (WWTP) effluents have been recognized as significant environmental AR reservoirs due to selective pressure generated by antibiotics and other compounds that are frequently detected in effluents. This review summarizes a myriad of recent studies that have assessed the impact of anthropogenic practices on AR in environmental bacterial communities, with specific emphasis on elucidating the potential effects of TWW irrigation on $\mathrm{AR}$ in the soil microbiome. Based on the current state of the art, we conclude that contradictory to freshwater environments where WWTP effluent influx tends to expand antibiotic-resistant bacteria (ARB) and antibiotic-resistant genes levels, TWW irrigation does not seem to impact AR levels in the soil microbiome. Although this conclusion is a
\end{abstract}

Responsible editor: Robert Duran

J. Gatica $\cdot$ E. Cytryn

Institute of Soil, Water and Environmental Sciences, Volcani

Center, Agricultural Research Organization, Bet Dagan, Israel

J. Gatica $(\square)$

Department of Agroecology and Plant Health, The Robert H. Smith Faculty of Agriculture, Food and Environment, The Hebrew University of Jerusalem, Jerusalem, Israel

e-mail: joao.gatica@mail.huji.ac.il

E. Cytryn $(\bowtie)$

P.O. Box 6, Bet Dagan 50250, Israel

e-mail: eddie@volcani.agri.gov.il cause for cautious optimism regarding the future implementation of TWW irrigation, we conclude that further studies aimed at assessing the scope of horizontal gene transfer between effluent-associated ARB and soil bacteria need to be further conducted before ruling out the possible contribution of TWW irrigation to antibiotic-resistant reservoirs in irrigated soils.

Keywords Treated wastewater · Irrigation · Soil · Antibiotic-resistant bacteria $\cdot$ Antibiotic-resistant genes

\section{Introduction}

The world is confronted by an ever increasing shortage of water, especially in arid and semiarid regions such as Africa, South Asia, Southern Europe, and the Middle East. In many of these regions, freshwater is not available for irrigation, and therefore, the reuse of treated or untreated wastewater is the sole water source for agriculture. However, standards are required to ensure safe use of wastewater and to avoid biological risks to the human population. In this context, the dissemination of antibiotic-resistant bacteria (ARB) and antibiotic-resistant genes (ARGs) from wastewater irrigation to natural soil and water environments is of public concern because it may contribute to global antibiotic resistance (AR). Here, we discuss the implications of wastewater reuse in agriculture and the impact of treated wastewater (TWW) irrigation on AR in the soil microbiome.

\section{Wastewater reuse in agriculture: benefits vs. risks}

Mankind is currently confronted with one of the greatest challenges in its history: how to adequately use its limited freshwater resources. In this context, the challenge 
implicates the use of water for drinking, agriculture, and the preservation of fragile freshwater ecosystems (Postel 2000).

The reuse of TWW, especially in agriculture, is an appealing and practical solution for water scarcity that significantly relieves pressure on water resources (Toze 2006; Zhang and Liu 1989). Additionally, water reuse can alleviate the discharge of effluents into the environment, avoiding in this way the deterioration of freshwater ecosystems associated with eutrophication and algal blooms (Toze 2006). The use of TWW in agricultural irrigation has also been found to have additional agronomic benefits associated with soil structure and fertility. According to Kiziloglu et al. (2007), wastewater has a high nutritive value that may improve plant growth, reduce fertilizer application rates, and increase productivity of poor fertility soils. Diverse studies have indeed shown that TWW irrigation increases soil organic matter (Mañas et al. 2009; Jueschke et al. 2008; Kiziloglu et al. 2007) as well as the concentrations of different nutrients involved in plant growth such as nitrogen $(\mathrm{N})$, phosphorus, iron, manganese, potassium, calcium, magnesium, and others (Akponikpe et al. 2011; Rezapour and Samadi 2011; Sacks and Bernstein 2011; Mañas et al. 2009; Gwenzi and Munondo 2008; Kim et al. 2007; Kiziloglu et al. 2007; Angin et al. 2005). Conversely, the use of TWW for irrigation can have detrimental effects on soil quality. These include increased salinity and decreased soil pH (Kiziloglu et al. 2007; Angin et al. 2005; Mohammad and Mazahreh 2003), as well as increased soil hydrophobicity (Tarchitzky et al. 2007; Graber et al. 2006).

Despite the obvious benefits of TWW irrigation, the human and environmental health implications of this process have opened a new controversial front in the public debate (Phung et al. 2011). Perhaps the most evident public health qualms are linked to the presence pathogens. Several studies have reported high count of total coliforms and fecal coliforms in crops irrigated with TWW (Akponikpe et al. 2011; Sacks and Bernstein 2011; Mutengu et al. 2007; Rai and Tripathi 2007), while others have detected bacterial pathogens such as Salmonella, Streptococci, Clostridium, Shigella, and Vibrio spp. (Mañas et al. 2009; Samie et al. 2009). Other human pathogens associated with wastewater reuse include helminthes, viruses, and protozoa (Carey et al. 2004; Caccio et al. 2003; Tree et al. 2003). The level of microbial contamination observed in recycled wastewater, soils, and crops depends on technical regulations based on national standards. In this context, posttreatment disinfection processes such as chlorination, ozonation, and UV radiation, shown to be successful treatments against microbial agents and pharmaceutical ingredients, can significantly reduce the risks associated with TWW irrigation (Hey et al. 2012; Martinez et al. 2011; Nikaido et al. 2010; Bernstein et al. 2008; An et al. 2007).

Irrigation of agricultural crops with recycled wastewater is also associated with several non-biological risk factors; perhaps the most significant being heavy metal contamination. In this context, different studies have shown the accumulation of heavy metals such as cadmium (Cd), nickel, chromium (Cr), lead, and other elements in soil and plants under wastewater irrigation regimen (Gupta et al. 2010; Bahmanyar 2008; Khan et al. 2008; Song et al. 2006; Wang et al. 2006; Mapanda et al. 2005). According to Gupta et al. (2010), among the heavy metals aforementioned, $\mathrm{Cd}$ and $\mathrm{Cr}$ are of greatest concern due to their high uptake rates in plants and their accumulation in tissue vegetal body parts; implicating a health hazard associated with the consumption of these heavy metal-contaminated vegetables over a long period of time.

A wide spectrum of persistent organic contaminants has been detected in soils irrigated with TWW, including polycyclic aromatic hydrocarbons, polychlorinated biphenyls, and organochlorine pesticides (Chen et al. 2011; Sun et al. 2009; Chen et al. 2005; Pedersen et al. 2003). In addition, there is a rising concern regarding the presence of emerging contaminants that include endocrine-disrupting chemicals and pharmaceutical and personal care products (PPCPs), a diverse collection of thousands of chemical substances that include prescription and over-the-counter therapeutic drugs, veterinary drugs, fragrances, and cosmetics (EPA 2012). Several studies have suggested that the behavior and possible accumulation of PPCPs in natural environments could have a potential impact on both soil and human health (Walker et al. 2012; Chen et al. 2011; Xu et al. 2009a). However, more significant than the direct toxicity of PPCPs themselves are the potential biological effects that these compounds may have on downstream ecosystems. Perhaps, the most crucial of these effects is augmentation of AR in environmental microbiomes due to selective pressure.

With the aim of reducing risks associated with wastewater reuse, the first national standard for wastewater reuse was created in Israel in 1953 (Tal 2006). Since then, many guidelines and quality standard have been designed and applied in both Israel and worldwide (Inbar 2007; Blumenthal et al. 2000), but none have proved to be universally applicable (Phung et al. 2011) and none have considered the potential environmental and public health impact of effluent-associated emerging contaminants and their biological implications.

\section{Persistence of pharmaceuticals in effluents and TWW- irrigated soils}

Certain pharmaceuticals are only partially metabolized in the body and, therefore, significant levels of these compounds and their metabolites are excreted and transported to wastewater treatment plants (WWTPs) (Xu et al. 2007). The removal or inactivation of these compounds in the 
WWTP depends on both the specific technology applied in the sewage plant and on the physical and chemical properties of each pharmaceutical compound (Monteiro and Boxall 2010). Nonetheless, many pharmaceutical compounds and their metabolites persist in WWTPs and are released in effluents even when rigorous tertiary disinfection methods are applied (Jelic et al. 2011).

PCPPs observed in the environment include analgesics and anti-inflammatories, antibiotics, antidepressants, antiepileptics, antineoplastic agents, $\beta$-blockers, hormones, different class of metabolites, and other pharmaceuticals (FattaKassinos et al. 2011b; Monteiro and Boxall 2010; Nikolaou et al. 2007). Specific PCPPs commonly detected in WWTPs effluent include ibuprofen, diclofenac, naproxen and ketoprofen (analgesic and anti-inflammatories), atenolol, metoprolol, and propanolol ( $\beta$-blockers), clofibric acid, bezafibrate and gemfibrozil (lipid regulator agent), carbamazepine (anti-seizure, antiepileptic), caffeine (stimulant), and triclosan (bactericide), which additionally are found in crops irrigated with TWW (Verlicchi et al. 2012; Bondarenko et al. 2012; Fenet et al. 2012; Chen et al. 2011; Fatta-Kassinos et al. 2011; Sim et al. 2011; Xu et al. 2009b; Chefetz et al. 2008; Topp et al. 2008; Kinney et al. 2006; Pedersen et al. 2003, 2005). Many antibiotic compounds are not degraded or only partially degraded in the body and often unused drugs are directly disposed of down drains (Kummerer and Henninger 2003). Additionally, several antibiotic compounds are not fully degraded in the WWTP process and are therefore released via effluents into the environment where they can select for antibiotic-resistant bacteria (Kummerer and Henninger 2003). Thus, antibiotics are considered pseudopersistent contaminants because they are continuously introduced into the environment (Shi et al. 2012). Antibiotic compounds consistently detected in WWTP effluents include azithromycin, clarithromycin, ciprofloxacin, erythromycin, norfloxacin, ofloxacin, sulfamethoxazole, and trimethoprim (Fatta-Kassinos et al. 2011b; Li and Zhang 2011; Sim et al. 2011; Ghosh et al. 2009; Watkinson et al. 2007). Additionally, some studies have detected antibiotics, such as erythromycin and tetracycline, in wastewaterirrigated soils (Chen et al. 2011; Kinney et al. 2006) and sulfamethoxazole and erythromycin have even been discovered in groundwater under land irrigated with wastewater effluents (Avisar et al. 2009; Siemens et al. 2008).

\section{Human health implications of AR and the emergence of environmental AR reservoirs}

According to Baquero et al. (2009), "antibiotics are among the most successful medical inventions, alleviating human morbidity and mortality; however, since they were introduced for therapy nearly 60 years ago, bacteria have developed different strategies to avoid their activity". Antibiotics are regularly used for treating infections and protecting human and animal health. In addition, they are frequently used to promote animal growth and improve feed efficiency in aquaculture and farming (Davies and Davies 2010; Baquero et al. 2009; Binh et al. 2008; Dzidic et al. 2008). However, the rapid emergence of AR since the development of antibiotics in the 1940s is extremely alarming, and some have gone as far as to state that we are approaching a "post-antibiotic era" (Alanis 2005). To exercise its action, an antibiotic compound needs to enter the bacterial cell at inhibitory or lethal concentrations, remain stable, and finally locate and interact with its target (Jayaraman 2009). However, bacteria can avoid one or more of the previously described steps by antibiotic inactivation, target modification, efflux pumps, target bypass, and noninheritable mechanisms such as persistence, biofilm production, and swarming (Jayaraman 2009; Dzidic et al. 2008).

Traditional study of bacterial AR has focused on isolation of clinically important resistant pathogens that proliferate in response to antibiotic treatment in nosocomial and community settings. However, a myriad of recent data suggests that environmental reservoirs are also strongly associated with the global proliferation of AR (Forsberg et al. 2012; D'Costa et al. 2006, 2011). Several studies have indicated that anthropogenic activities such as aquaculture, application of manure and biosolids to soil, and environmental discharge of WWTP effluents can contribute to expansion of these environmental AR reservoirs (Munir and Xagoraraki 2011; Davies and Davies 2010; Knapp et al. 2010; Binh et al. 2008), and these reservoirs can serve as "hotspots" for the spread of ARGs and ARB through food and water, with unsuspected consequences for human health (Martinez 2009b; Zhang et al. 2009).

ARGs are often carried on broad host range mobile genetic elements (MGEs) (Byrne-Bailey et al. 2011; Akiyama et al. 2010; Binh et al. 2008), which are of particular concern because these vectors may be disseminated from environmental hotspots through water and food webs into clinically relevant pathogenic or opportunistic bacteria (Van Meervenne et al. 2012; Jayaraman 2009). Benveniste and Davies (1973) first suggested a link between environmental and clinical AR after detecting high similarities between gentamicin-resistant enzymes from soil-associated Actinomycetes and enzymes that confer the same resistance in human pathogens such Escherichia coli, Pseudomonas aeruginosa, Klebsiella pneumonia, and Staphylococcus aureus. Although a direct transfer of genetic information from one to other was not demonstrated, the authors suggested an evolutionary relationship between these enzymes in non-phylogenetically related bacteria. Highly conclusive evidence demonstrating the horizontal transfer of ARGs between soil and clinical isolates was recently presented by Forsberg et al. (2012), who applied functional 
metagenomics and high-throughput screening to large collections of soil isolates. The authors detected a wide array of functionally diverse ARGs in the soil isolates with perfect nucleotide identity to human pathogens. The data suggests that horizontal gene transfer (HGT) of AR genes between soil and clinical environments not only occurs, but appears to be a relatively common phenomenon.

\section{Release of ARB and ARGs from WWTPs}

Antibiotic compounds have been found to select for resistance even when concentrations are orders of magnitude below clinical breakpoints (Gullberg et al. 2011), and therefore, persistent antibiotics such as erythromycin, tetracycline, or sulfamethoxazole may select for antibiotic resistance in downstream terrestrial and aquatic environments. In addition, heavy metals and biocides such zinc (Peltier et al. 2010) and triclosan (Ciusa et al. 2012; Aiello et al. 2005) can promote AR in bacteria in a process known as cross-selection (Martinez 2009a). In this context, WWTPs are a favorable environment for propagation of AR because they assemble high concentrations of bacteria (often in biofilms), nutrients, and antimicrobial agents (LaPara et al. 2011; Novo and Manaia 2010; Xi et al. 2009; DaCosta et al. 2006).

In the last years, more attention has been put on the role of WWTPs as reservoirs of ARB and ARGs, and different techniques have been used to assess their presence in different stages of wastewater treatment, as well as in downstream environments. Gao et al. (2012) found high concentrations of tetracycline (tet $\mathrm{O}$ and tet $\mathrm{W}$ ) and sulfonamide (sulI) resistance genes $\left(9.12 \times 10^{5}-1.05 \times 10^{6}\right.$ gene copy $\left.\# / \mathrm{mL}\right)$ and high levels of ARB $\left(1.05 \times 10^{1}-3.09 \times 10^{3} \mathrm{CFU} / \mathrm{mL}\right)$ in the final effluent of a wastewater treatment plant in Michigan. An additional study found significant levels of ARGs (tetO, tet $\mathrm{W}$, and sulI) and ARB in raw sewage, effluent, and biosolid samples of a WWTP, although increased levels of wastewater treatment significantly reduced the amount of ARGs and ARBs in the treated effluent, especially when more advanced technologies such as membrane biological reactors were used (Munir et al. 2011). Previous reports have found other important ARGs such as ampC and van $\mathrm{A}$ that confer resistance to ampicillin and vancomycin, respectively, in wastewater samples collected from five municipal treatment plants; additional studies found the methicillin-resistant gene mecA, in samples taken from clinical wastewater (Volkmann et al. 2004). Other studies have assessed AR in mobile elements such as plasmids, transposons, and integrons in WWTPs. In this context, a plasmid metagenome analysis from the final effluent of a WWTP in Germany revealed 140 clinically relevant ARGs including genes conferring resistance to aminoglycosides, $\beta$-lactams, chloramphenicol, fluoroquinolones, macrolides, rifampicin, tetracycline, trimethoprim, and sulfonamide as well as multidrug efflux and multidrug resistance genes (Szczepanowski et al. 2009). Screening of multiresistant Enterobacteriaceae isolates from different stages of a municipal WWTP in Poland revealed the presence of integronpositive isolates in the final effluent; all of whom were multiresistant to at least three different antimicrobials (Mokracka et al. 2012). A number of recent studies in Minnesota and Colorado detected high levels of genes encoding resistance to tetracycline $(\operatorname{tet} \mathrm{O}, \operatorname{tet} \mathrm{X}$, and tet $\mathrm{W}$ in Minnesota and tet $\mathrm{O}$ and tet $\mathrm{W}$ in Colorado) and the class 1 integron genes (intI1) in both tertiary treated effluents and in rivers receiving these effluents, demonstrating the transfer capacity of ARB and ARGs from WWTPs to aquatic environments (LaPara et al. 2011; Pruden et al. 2006). This phenomenon was established in a recent comprehensive study by Czekalski et al. (2012) who found that ARGs and ARB released from WWTP effluents were disseminated into Lake Geneva resulting in significant proliferation of AR levels in both the water column and in sediments that were proximal to the point of effluent infiltration.

\section{Native AR in soil bacteria}

Although human-associated activities may influence levels of $\mathrm{AR}$ in environmental microbiomes, it is becoming increasingly clear that ARB and ARGs are often highly prevalent in natural or undisturbed soils, assumedly because soil microorganisms are the main producers of clinical antibiotic compounds (Aminov and Mackie 2007). In this context, D'Costa et al. (2006), indicated that the soil could serve as an underrecognized reservoir for antibiotic resistance that has already emerged or has the potential to emerge in clinically important bacteria. The authors coined the term "resistome" to describe the collection of all the ARGs and their precursors in a defined natural environment. Several recent studies have strengthened the resistome hypothesis through the detection of ARGs in a wide array of undisturbed environments. For instance, soil bacterial genes encoding $\beta$-lactamases were detected in an undisturbed soil in Alaska (Allen et al. 2009), and recently, multiresistant bacteria were isolated from a deep and undisturbed cave in the Carlsbad Caverns National Park (USA) (Bhullar et al. 2012). Interesting, three Streptomyces isolates from this cave were highly resistant to daptomycin (MIC $\geq$ $256 \mu \mathrm{g} / \mathrm{mL}$ ) which is employed as a last resort antibiotic in the treatment of drug-resistant Gram-positive pathogens (Bhullar et al. 2012). Perhaps, the most significant indication that $\mathrm{AR}$ is a natural phenomenon was provided by recent metagenomic-based analysis of authenticated ancient DNA from 30,000-year-old permafrost sediments in northern Canada. The authors detected a highly diverse collection of 
genes encoding resistance to $\beta$-lactam, tetracycline, and glycopeptide antibiotics and most surprisingly identified a vancomycin resistance element (VanA) that was highly similar in structure and function to modern variants of the gene vanA identified in clinical pathogens (D'Costa et al. 2011). The results detailed above strongly suggest that native AR in the soil microbiome has been underestimated until now and more studies are required to understand the real scope of the this phenomenon in the soil microbiome.

\section{Impact of wastewater irrigation on the soil microbiome}

As previously indicated, TWW irrigation is crucial for agriculture, especially in arid and semiarid areas of the world. However, based on the above-cited studies, TWW may harbor antibiotic compounds and metabolites as well as ARGs and ARB, which could enhance AR in the soil microbiome.

Impact of TWW irrigation on soil microbiome diversity and activity

Microbial activity, a key indicator of soil quality, is often used to assess the impact of anthropogenic and agronomic practices on soil vitality. Several studies have addressed the effect of TWW irrigation on soil microbial activity. Filip et al. $(1999,2000)$ reported higher microbial activity, measured by the activity of $\beta$-glucosidase, $\beta$-acetylglucosaminidase, proteinase, and phosphatase, in two soils irrigated with primary effluent for 100 years, relative to soils that were never irrigated. Interestingly, when these soils were left unirrigated for 20 years, their microbial activities returned to levels characteristic of the nonirrigated soils. Additionally, the application of TWW significantly stimulated the development of copiotrophic bacteria and fungi, whereas the original soil microbiome was dominated by oligotrophic bacteria (require less nutrient to growth). The authors also detected strong increases in microbial biomass in soils irrigated with TWW. A study by Hidri et al. (2010) also found that long-term irrigation with TWW resulted in increased soil microbial abundance and TWW irrigation induced a particular composition of the bacterial and fungal communities. However, the magnitude and specificity of these changes were significantly correlated to the duration of irrigation. Additional studies conducted under different conditions with different soil types and TWW irrigation regimens also showed higher microbial activity in soils irrigated with TWW, but when the irrigation was suspended, the microbial activity returned to nonirrigated or freshwater-irrigated soil levels (Adrover et al. 2012; Elifanz et al. 2011; Meli et al. 2002), demonstrating the high resilience of the soil microbiome.
Microbial diversity and community structure are considered to be excellent indicators of soil health, and these methods have been implemented to assess the impact of anthropogenic activities on soil microbiota. In this context, Oved et al. (2001) and Ndour et al. (2008) evaluated the fate of ammonia-oxidizing bacteria (AOB) in two soils under different wastewater irrigation regimens (short- and longterm irrigated soils, respectively). In both cases, the results suggested that wastewater irrigation produces shifts in AOB population in the soil, as compared to soil irrigated with freshwater or groundwater, respectively. By applying denaturing gradient gel electrophoresis (DGGE) and subsequent cloning of excised DGGE bands, the Oved study revealed that the AOB population in wastewater-irrigated soils is dominated by Nitrosomonas-like strains, while in freshwaterirrigated soils, the AOB populations were dominated by Nitrosospira-like strains. However, despite shifts in the microbial community between wastewater- and freshwaterirrigated soils, no apparent shifts were observed in community function. Ndour et al. (2008) also saw no differences between the two treatments in microbial biomass or microbial activity, measured as FDA activity; presumably, due to the similar levels of organic $\mathrm{C}$ and $\mathrm{N}$ among the treatments. In contrast to the above-cited studies, Truu et al. (2009) reported that short-term municipal wastewater irrigation of a shortrotation willow coppice weakly affected soil chemical, microbiological, and biochemical properties. However, these changes were attributed to the willow growth rather than wastewater irrigation.

In general, the studies detailed above indicate that TWWirrigated soils are characterized by a certain tendency for higher microbial activity, higher microbial biomass, and higher resilience than concurrent freshwater-irrigated soils. However, it should be noted that the final effect of TWW irrigation on the soil microbiome will depend on the compounds present in the TWW and their concentration, the duration of irrigation, and the properties of the soil irrigated. Based on currently available data, it appears that TWWinduced changes in microbial activity and community composition are primarily associated with increased salinity and levels of dissolved organic matter relative to and freshwaterirrigated soils. Although residual levels of PPCPs and antibiotics have been detected in TWW-irrigated soils, currently available methodologies are unable to link the presence of these compounds to soil microbial activity or community composition. To seek changes in the whole microbial activity as a result of soil disturbances, it may be advisable to observe the community dynamics of less abundant components of the soil microbiota because these taxonomic groups can be more sensitive than widespread groups in evidencing changes in the microbiome in response to soil disturbances (Gelsomino et al. 2006). The high abundance of AR in the Actinobacteria class may make this group a key target for 
assessing the impact of TWW irrigation on soil community composition.

Impact of TWW irrigation on ARB and ARG abundance

One of the most significant contributions to the understanding of the effects of TWW irrigation on the magnitude of soil ARB and ARGs was recently published by Negreanu et al. (2012). In this study, four soils with different physicochemical properties were irrigated in tandem with freshwater or TWW and were assessed by standard culture-based isolation methods and culture-independent molecular analyses. Resistance to four clinically relevant antibiotic families - tetracycline, erythromycin, sulfonamide, and ciprofloxacin - was evaluated. The authors monitored six different ARGs that confer resistance to the abovementioned antibiotics, which had previously been detected in wastewater effluents. The genes chosen were qnrA gene that confers resistance to fluoroquinolones in Gram-negative bacteria, tet $\mathrm{O}$ linked to tetracycline resistance, $\operatorname{sul}(1)$ and $\operatorname{sul}(2)$ genes that confer resistance to sulfonamides, and erm(B) and erm(F) associated with resistance to macrolide, lincosamide, and streptogramin antibiotics. Surprisingly, our findings showed that the relative abundance of resistant isolates, and the levels of ARGs, was either identical or often even higher in freshwater-irrigated soils relative to the TWW-irrigated soils, despite significant loads of ARB and ARGs in the TWW that was used for irrigation. These results indicate that residual antibiotic concentrations associated with WWTP effluents do not seem to exert selective pressure that is significant enough to induce propagation of ARGs in TWW-irrigated soils and that TWWassociated ARB and ARGs do not persist in the irrigated soils. The authors concluded that the high numbers of resistant bacteria that enter the soils through TWW irrigation are not able to compete or survive in the soil environment and that the high levels of ARB and ARGs observed in both freshwaterand TWW-irrigated soils are predominantly associated with the native soil resistome. Preliminary bench-scale mesocosm experiments performed in our lab (Gatica unpublished), in which soils were subjected to an irrigation regime of dilute organic media amended with clinical concentrations of antibiotics in $250 \mathrm{ml}$ plastic containers, showed no changes in microbial activity and very little changes in microbial community composition in relation to non-antibiotic-amended soils, supporting the notion that environmentally relevant antibiotic concentrations do not appear to significantly exert selective pressure on the soil microbiome.

Similar results were obtained in a recent study conducted in Arizona by McLain and Williams (2010), who compared AR profiles of Enterococcus isolates (screened against 16 antibiotic compounds) from soils irrigated for more than 20 years with either recharged municipal TWW or groundwater. The authors found high levels of AR in isolates in both
TWW- and freshwater-irrigated soils, although AR patterns in the two soils differed. For example, isolates from the TWW-irrigated soils showed high resistance to daptomycin, and lincomycin, while isolates from the groundwater-filled pond were highly resistant to erythromycin, tetracycline, ciprofloxacin, and tylosin tartrate. Surprisingly, isolates from the freshwater soils showed higher levels of multiresistance than those isolated in the TWW-irrigated soils. Although the possibility of selective pressure due to low levels of antibiotic exposure from unknown sources cannot be rejected, the results reflect natural occurrence of AR in soils prior to TWW irrigation and suggest that ARB that entered the soil from the TWW did not survive in the soil environment. Supporting this idea, a recent study that assessed the survival of greywater- and TWW-associated bacterial pathogens in irrigated soils showed that while a high number of pathogens were present in TWW and greywater, no significant differences were observed between TWW/greywater-irrigated soils and freshwater-irrigated soil (Orlofsky et al. 2011).

\section{Open questions}

When assessing the impact of TWW irrigation on AR in the soil microbiome, we should not ignore the mechanisms that govern the gene exchange at inter- and intra-species levels. As described above, ARGs are often associated with MGEs, which can be transferred across a broad spectrum of bacteria. MGEs include conjugative transposable elements such as transposons and insertion sequences, integrative conjugative elements, or integrons and plasmids (Sorensen et al. 2005; Van Elsas and Bailey 2002). HGT of these elements can increase the spread of ARGs in pathogenic and nonpathogenic bacteria by three principal mechanisms: conjugation that involves plasmid transfer by direct cell-to-cell contact; transformation, which involves the uptake of free DNA via cell wall and integration into the bacterial genome; and transduction by phage-mediated gene transfer (Sorensen et al. 2005).

TWW irrigation can introduce plasmids or other MGEs harboring ARGs to the soil microbiome, and the high mobility and versatility of these elements may contribute to AR propagation far beyond intrinsic elements that are chromosomally harbored in many native soil bacteria. Therefore, when considering the impact of anthropogenic practices on the soil microbiome, it is not only necessary to assess the abundance of ARGs in soil, but also to specifically determine ARG levels that are associated with MGEs, because these elements are the most crucial from a public health perspective. The stability of plasmids and other MGEs in the environment is strongly dictated by a wide array of abiotic parameters such as soil type, micro and macronutrient availability, soil moisture, temperature, $\mathrm{O}_{2}$, and $\mathrm{pH}$ (Rahube and 
Yost 2010; Van Elsas and Bailey 2002). Future models designed to estimate the effect of TWW irrigation on the propagation of soil AR will need to integrate these factors as well. Furthermore, as presented by Martinez et al. (2007), there are several obstacles that need to be overcome to enable ARG HGT from environmental bacteria to the humanassociated microbiota: first, only ARGs that can coexist with human pathogens will contribute to resistance; second, only those genes recruited by gene transfer systems compatible with human pathogens will be transferred; third, elements that produce strong fitness cost in their host will be counter selected; and fourth, when a resistance determinant is acquired by HGT, the probabilities for a new acquisition will be low, unless antibiotic selective pressure changes. However, although many ARGs may disappear from a given habitat due to their high fitness cost, other ARGs may remain in the environment because of their fitness cost is low, and this cost is compensated or even beneficial (Baquero et al. 2009).

The release of TWW effluents into the soil and the balance that governs HGT in bacteria generate important questions associated with the understanding of AR evolution: Is TWW irrigation a significant source of ARGs to native soil bacteria? Can unknown ARGs from native soil bacteria be transferred by HGT to opportunistic and pathogenic bacteria that enter the soil through TWW irrigation? Are the ARGs transferred from environmental bacteria to human pathogens, and if so, do they persistent over time? Do soils irrigated with TWW become ARG hotspots and how frequent does HGT occur in these soils? Although emerging data suggest that this is not the case, the answer to these questions to a large extent is still an enigma and requires additional in-depth analyses.

\section{Conclusions}

The use of TWW in agriculture is of growing importance, especially in arid and semiarid areas of the world, because it alleviates pressure on natural water sources. However, the treatment of wastewater does not assure the successful removal of all biological and chemical contaminants and differences in quality effluents can be observed among different WWTPs. Thus, biological components and active compounds can be transported from WWTP effluents to terrestrial environments such as plants and soils, impacting in different ways both soil properties and the ecosystems that they support. Certain antibiotics are highly persistent in WWTPs, and ARGs and ARB can be enriched in the wastewater treatment processes, and subsequently, these elements can be transported to the soil by irrigation, where they may be incorporated into the native soil microbiome. Although recent studies seem to indicate that irrigation with TWW does not significantly induce AR reservoirs in soil, the impact of all of the abovementioned factors is not yet clear especially in the context of mobile ARG transfer between TWW-associated bacteria and the soil. Additional studies are required to answer these questions and to determine the efficient WWTP processes for optimal reduction of ARGs, in order to ensure safe application of TWW for irrigation.

Open Access This article is distributed under the terms of the Creative Commons Attribution License which permits any use, distribution, and reproduction in any medium, provided the original author(s) and the source are credited.

\section{References}

Adrover M, Farrus E, Moya G, Vadell J (2012) Chemical properties and biological activity in soils of Mallorca following twenty years of treated wastewater irrigation. J Environ Manage 95:188-192

Aiello A, Marshall B, Levy S, Della-Latta P, Lin S, Larson E (2005) Antibacterial cleaning products and drug resistance. Emerg Infect Dis 11:1565-1570

Akiyama T, Asfahl L, Savin C (2010) Broad-host-range plasmids in treated wastewater effluent and receiving streams. J Environ Qual 39:2211-2215

Akponikpe P, Wima K, Yakouba H, Mermoud A (2011) Reuse of domestic wastewater treated in macrophyte ponds to irrigate tomato and eggplants in semi-arid West-Africa: benefits and risks. Agr Water Manag 98:834-840

Alanis J (2005) Resistance to antibiotics: are we in the post-antibiotic era? Arch Med Res 36:697-705

Allen H, Moe L, Rodbumrer J, Gaarder A, Handelsman J (2009) Functional metagenomics reveals diverse $\beta$-lactamases in a remote Alaskan soil. ISME J 3:243-251

Aminov R, Mackie R (2007) Evolution and ecology of antibiotic resistance genes. FEMS Microbiol Lett 271:147-161

An Y, Yoon C, Jung K, Ham J (2007) Estimating the microbial risk of E. coli in reclaimed wastewater irrigation on paddy field. Environ Monit Assess 129:53-60

Angin I, Yaganoglu P, Turan M (2005) Effects of long-term wastewater irrigation on soil properties. J Sustain Agr 26:31-42

Avisar D, Lester Y, Ronen D (2009) Sulfamethoxazole contamination of a deep phreatic aquifer. Sci Total Environ 407:4278-4282

Bahmanyar M (2008) Cadmium, nickel, chromium, and lead levels in soils and vegetables under long-term irrigation with industrial wastewater. Comm Soil Sci Plant Anal 39:2068-2079

Baquero F, Alvarez-Ortega C, Martinez J (2009) Ecology and evolution of antibiotic resistance. Environ Microbiol Rep 1:469-476

Benveniste R, Davies J (1973) Aminoglycoside antibiotic-inactivating enzymes in Actinomycetes similar to those present in clinical isolates of antibiotic-resistant bacteria. PNAS 70:2276-2280

Bernstein N, Guetsky R, Friedman H, Bar-Tal A, Rot I (2008) Monitoring bacterial populations in an agricultural greenhouse production system irrigated with reclaimed wastewater. J Hortic Sci Biotech 83:821-827

Bhullar K, Waglechner N, Pawlowski A, Koteva K, Banks E, Johnston M, Barton H, Wright G (2012) Antibiotic resistance is prevalent in an isolated cave microbiome. PLoS One 7:1-11

Binh C, Heuer H, Kaupenjohann M, Smalla K (2008) Piggery manure used for soil fertilization is a reservoir for transferable antibiotic resistance plasmids. FEMS Microb Ecol 66:25-37

Blumenthal U, Mara D, Peasey A, Ruiz-Palacios G, Stott R (2000) Guidelines for the microbiological quality of treated wastewater 
used in agriculture: recommendations for revising WHO guidelines. Bull WHO 78:1104-1116

Bondarenko S, Gan J, Ernst F, Green R, Baird J, McCullough M (2012) Leaching of pharmaceuticals and personal care products in turfgrass soils during recycled water irrigation. J Environ Qual 41:1268-1274

Byrne-Bailey G, Gaze H, Zhang L, Kay P, Boxall A, Hawkey M, Wellington $H$ (2011) Integron prevalence and diversity in manured soil. Appl Environ Microbiol 77:684-687

Caccio S, De Giacomo M, Aulicino F, Pozio E (2003) Giardia cystis in wastewater treatment plants in Italy. Appl Environ Microbiol 69:3393-3398

Carey C, Lee H, Trevors J (2004) Biology, persistence and detection of Cryptosporidium parvum and Cryptosporidium homynis oocyst. Water Res 38:818-868

Chefetz B, Mualem T, Ben-Ari J (2008) Sorption and mobility of pharmaceutical compounds in soil irrigated with reclaimed wastewater. Chemosphere 73:1335-1343

Chen Y, Wuang C, Wang Z (2005) Residues and source identification of persistent organic pollutants in farmland soils irrigated by effluents from biological treatment plants. Environ Int 31:778783

Chen F, Ying G, Kong L, Wang L, Zhao J, Zhou L, Zhang L (2011) Distribution and accumulation of endocrine-disrupting chemicals and pharmaceuticals in wastewater irrigated soils in Hebei, China. Environ Pollut 159:1490-1498

Ciusa M, Furi L, Knight D, Decorosi F, Fondi M, Raggi C, Coelho J, Aragones L, Moce L, Visa P, Freitas A, Baldassarri L, Fani R, Viti C, Orefici G, Martinez J, Morrissey I, Oggioni M (2012) A novel resistance mechanism to triclosan that suggest horizontal gene transfer and demonstrates a potential selective pressure for reduced biocide susceptibility in clinical strains of Staphylococcus aureus. Int J Antimicrob Ag 40:210-220

Czekalski N, Berthold T, Caucci S, Egli A, Burgmann H (2012) Increased levels of multiresistant bacteria and resistance genes after wastewater treatment and their dissemination into Lake Geneva, Switzerland. Front Microbio 3:1-18

D'Costa V, McGrann K, Hughes D, Wright G (2006) Sampling the antibiotic resistome. Science 311:374-377

D'Costa V, King C, Kalan L, Morar M, Sung W, Schwarz C, Froese D, Zazula G, Calmels F, Debruyne R, Golding B, Poinar H, Wright G (2011) Antibiotic resistance is ancient. Nature 477:457-461

DaCosta P, Vaz-Pires P, Bernardo F (2006) Antimicrobial resistance in Enterococcus spp. isolate in inflow, effluent and sludge from municipal sewage water treatment plants. Water Res 40:17351740

Davies J, Davies D (2010) Origins and evolution of antibiotic resistance. Microbiol Mol Biol R 74:417-433

Dzidic S, Suskovic J, Kos B (2008) Antibiotic resistance mechanisms in bacteria: biochemical and genetic aspects. Food Technol Biotechnol 46:11-21

Elifanz H, Kautsky L, Mor-Yosef M, Tarchitzky J, Bar-Tal A, Chen Y, Minz D (2011) Microbial activity and organic matter dynamics during 4 years of irrigation with treated wastewater. Microb Ecol 62:973-981

EPA (2012) Pharmaceutical and personal care products (PPCPs). EPA web. http://www.epa.gov/ppcp/. Accessed 10 Nov 2012

Fatta-Kassinos D, Hapeshi E, Achilleos A, Meric S, Gros M, Petrovic M, Barcelo D (2011a) Existence of pharmaceutical compounds in tertiary-treated urban wastewater that is utilized for reuse applications. Water Resour Manag 25:1183-1193

Fatta-Kassinos D, Kalavrouziotis I, Koukoulakis P, Vasquez M (2011b) The risk associated with wastewater reuse and xenobiotics in the agroecological environment. Sci Total Environ 409:3555-3563

Fenet H, Mathieu O, Mahjoub O, Li Z, Hillaire-Buyz D, Casellas C, Gomez E (2012) Carbamazepine, carbamazepine epoxide, and dihydroxycarbamazepine sorption to soil and occurrence in a wastewater reuse site in Tunisia. Chemosphere 88:4954

Filip Z, Kanazawa S, Berthelin J (1999) Characterization of effects of a long-term wastewater irrigation on soil quality by microbiological and biochemical parameters. J Plant Nutr Soil Sc 162:409-413

Filip Z, Kanazawa S, Berthelin J (2000) Distribution of microorganisms, biomass ATP, and enzymes activities in organic and mineral particles of a long-term wastewater irrigated soil. J Plant Nutr Soil Sc 163:143-150

Forsberg K, Reyes A, Wang B, Selleck E, Sommer M, Dantas G (2012) The shared antibiotic resistome of soil bacteria and human pathogens. Science 337:1107-1111

Gao P, Munir M, Xagoraraki I (2012) Correlation of tetracycline and sulfonamide antibiotics with corresponding resistance genes and resistant bacteria in a conventional municipal wastewater treatment plant. Sci Total Environ 421:173-183

Gelsomino A, Badalucco L, Ambrosoli R, Crecchio C, Puglisi E, Meli S (2006) Changes in chemical and biological soil properties as induced by anthropogenic disturbance: a case study of an agricultural soil under recurrent flooding by wastewaters. Soil Biol Biochem 38:2069-2080

Ghosh G, Okuda T, Yamashita N, Tanaka H (2009) Occurrence and elimination of antibiotics at four sewage treatment plants in Japan and their effects on bacterial ammonia oxidation. Water Sci Technol 59:779-786

Graber E, Ben-Arie O, Wallach R (2006) Effect of simple disturbance on soil water repellency determination in sandy soils. Geoderma 136:11-19

Gullberg E, Cao S, Berg O, Ilback C, Sandegren L, Hughes D, Andersson I (2011) Selection of resistant bacteria at very low antibiotic concentrations. PLoS Pathog 7:1-9

Gupta S, Satpati S, Nayek S, Garai D (2010) Effect of wastewater irrigation on vegetables in relation to bioaccumulation of heavy metals and biochemical changes. Environ Monit Assess 165:169177

Gwenzi W, Munondo R (2008) Long-term impacts of pasture irrigation with treated sewage effluent on nutrient status of a sandy soil in Zimbabwe. Nutr Cycl Agroecosys 82:197-207

Hey G, Ledin A, la Cour JJ, Andersen H (2012) Removal of pharmaceuticals in biologically treated wastewater by chlorine dioxide or peracetic acid. Environ Technol 33:1041-1047

Hidri Y, Bouziri L, Maron P, Anane M, Jedidi N, Hassan A, Ranjard L (2010) Soil DNA evidence for altered microbial diversity after long-term application of municipal wastewater. Agron Sustain Dev 30:423-431

Inbar Y (2007) New standards for treated wastewater reuse in Israel. In: Zaidi M (ed) Wastewater reuse-risk assessment, decision-making and environmental security, Springer Netherlands, pp 291296.

Jayaraman R (2009) Antibiotic resistance: an overview of mechanisms and a paradigm shift. Curr Sci 96:1475-1484

Jelic A, Gros M, Ginebra A, Cespedes-Sanchez R, Ventura F, Petrovic M, Barcelo D (2011) Occurrence partition and removal of pharmaceutical in sewage water and sludge during wastewater treatment. Water Res 45:1165-1176

Jueschke E, Marschner B, Tarchitzky J, Chen Y (2008) Effects of treated wastewater irrigation on the dissolved and soil organic carbon in Israeli soils. Water Sci Technol 57:727-733

Khan S, Cao Q, Zheng Y, Huang Y, Zhu Y (2008) Health risks of heavy metals in contaminated soils and food crops irrigated with wastewater in Beijing, China. Environ Pollut 152:686692

Kim S, Park S, Lee J, Benham B, Kim H (2007) Modeling and assessing the impact of reclaimed wastewater irrigation on the 
nutrition loads from an agricultural watershed containing rice paddy fields. J Environ Sci Heal A 42:305-315

Kinney C, Furlong E, Werner S, Cahill J (2006) Presence and distribution of wastewater-derived pharmaceuticals in soil irrigated with reclaimed water. Environ Toxicol Chem 25:317-326

Kiziloglu F, Tuean M, Sahin U, Angin I, Anapali O, Okuroglu M (2007) Effects of wastewater irrigation on soil and cabbageplant (Brassica olereacea var. capitate cv. Yavola-1) chemical properties. J Plant Nutr Soil Sc 170:166-172

Knapp W, Dolfing J, Ehlert I, Graham W (2010) Evidence of increasing 429 antibiotic resistance gene abundances in archived soils since 1940. Environ Sci Tech 44:580-587

Kummerer K, Henninger A (2003) Promoting resistance by the emission of antibiotics from hospitals and households into effluent. Clinic Microbiol Infec 9:1203-1214

LaPara T, Burch T, McNamara P, Tan D, Yan M, Eichmiller J (2011) Tertiary-treated municipal wastewater is significant point source of antibiotic resistance genes into Duluth-Superiro Harbor. Environ Sci Technol 45:9543-9549

Li B, Zhang T (2011) Mass flow and removal of antibiotics in two municipal wastewater treatment plants. Chemosphere 83:12841289

Mañas P, Castro E, Heras J De las (2009) Irrigation with treated wastewater: effects on soil, lettuce (Lactuca sativa) crop and dynamics of microorganisms. J Environ Sci Heal A 44:12611273

Mapanda F, Mangwayana E, Nyamangara J, Giller K (2005) The effect of long-term irrigation using wastewater on heavy metal contents of soils under vegetables in Harare, Zimbabwe. Agr Ecosyst Environ 107:151-165

Martinez J (2009a) Environmental pollution by antibiotics and by antibiotic resistance determinants. Environ Pollut 157:28932902

Martinez J (2009b) The role of natural environments in the evolution of resistance traits in pathogenic bacteria. Proc Biol Sci 276:25212530

Martinez J, Baquero F, Andersson D (2007) Predicting antibiotic resistance. Nature 5:958-965

Martinez S, Perez-Parra J, Suay R (2011) Use of ozone in wastewater treatment to produce water suitable for irrigation. Water Resour Manag 25:2109-2124

McLain J, Williams C (2010) Development of antibiotic resistance in bacteria of soils irrigated with reclaimed wastewater. Dissertation, Phoenix convention center, Arizona

Meli S, Porto M, Belligno A, Buffo S, Mazzatura A, Scopa A (2002) Influence of irrigation with lagooned urban wastewater on chemical and microbiological soil parameters in a citrus orchard under Mediterranean condition. Sci Total Environ 285:69-77

Mohammad M, Mazahreh N (2003) Changes in soil fertility parameters in response to irrigation of forage crops with secondary treated wastewater. Comm Soil Sci Plant Anal 34:181-1294

Mokracka J, Koczura R, Kaznowski A (2012) Multiresistant Enterobacteriaceae with class 1 and class 2 integrons in a municipal wastewater treatment plant. Water Res 46:3353-3363

Monteiro S, Boxall A (2010) Occurrence and fate of human pharmaceutical in the environment. Rev Environ Contam T 202:53-154

Munir M, Xagoraraki I (2011) Levels of antibiotic resistance genes in manure, biosolids and fertilized soils. J Environ Qual 40:248-255

Munir M, Wong K, Xagoraraki I (2011) Release of antibiotic resistant bacteria and genes in the effluent of biosolids of five wastewater utilities in Michigan. Water Res 45:681-693

Mutengu S, Hoko Z, Makoni F (2007) An assessment of the public health hazard potential of wastewater reuse for crop production. A case of Bulawayo City, Zimbabwe. Phys Chem Earth 32:11951203
Ndour N, Baudoin E, Guisse A, Seck M, Khouma M, Brauman A (2008) Impact of irrigation water quality in soil nitrifying and total bacterial communities. Biol Fert Soils 44:797-803

Negreanu Y, Pasternack Z, Jurkevitch E, Cytryn E (2012) Impact of treated wastewater irrigation on antibiotic resistance in agricultural soils. Environ Science Technol 46:4800-4808

Nikaido M, Tonani K, Juliao F, Trevilato T, Takayanagui A, Sanchez S, Domingo J, Segura-Muñoz S (2010) Analysis of bacteria, parasites and heavy metals in lettuce (Lactuca sativa) and rocket salad (Eruca sativa L.) irrigated with treated effluent from a biological treated wastewater plant. Biol Trace Elem Res 34:342-351

Nikolaou A, Meric S, Fatta D (2007) Occurrence patterns of pharmaceuticals in water and wastewater environments. Anal Bioanal Chem 387:1225-1234

Novo A, Manaia C (2010) Factors influencing antibiotic resistance burden in municipal wastewater treatment plants. Environ Biotech 87:1157-1166

Orlofsky M, Gillor O, Bernstein N, Shapiro K, Miller W, Wuertz S (2011) The correlation between fecal indicator bacteria and pathogens in effluent irrigated tomatoes. 11th Worldwide Workshop for Young Environmental Scientists. Arcueil, France

Oved T, Shaviv A, Goldrath T, Mandelbaum R, Minz D (2001) Influence of effluent irrigation on community composition and function of ammonia-oxidizing bacteria in soil. Appl Environ Microbiol 67:3426-3433

Pedersen J, Yager M, Suffet I (2003) Xenobiotic organic compounds in runoff from fields irrigated with treated wastewater. J Agr Food Chem 51:1360-1372

Pedersen J, Soliman M, Suffet I (2005) Human pharmaceuticals, hormones and personal care product ingredients in runoff from agricultural fields irrigated with treated wastewater. J Agr Food Chem $56: 1625-1632$

Peltier E, Vincent J, Finn C, Graham D (2010) Zinc-induced antibiotic resistance in activated sludge bioreactors. Wat Res 44:3829-3836

Phung M, Pham T, Castle J, Rodgers J Jr (2011) Application of water quality guidelines and water quantity calculations to decisions for beneficial use of treated water. App Water Sci 1:85-101

Postel S (2000) Entering an era of water scarcity: the challenges ahead. Ecol Appl 10:941-948

Pruden A, Pei R, Storteboom H, Carlson K (2006) Antibiotic resistance genes as emerging contaminants: studies in northern Colorado. Environ Sci Technol 40:7445-7450

Rahube T, Yost C (2010) Antibiotic resistance plasmids in wastewater treatment plants and their possible dissemination into the environment. AJB 9:9183-9190

Rai P, Tripathi B (2007) Microbial contamination in vegetables due to irrigation with partially treated municipal wastewater in a tropical city. Int j Environ Heal R 17:389-395

Rezapour S, Samadi A (2011) Soil quality response to long-term wastewater irrigation in inceptisols from a semi-arid environment. Nutr Cycl Agroecosys 91:269-280

Sacks M, Bernstein N (2011) Utilization of reclaimed wastewater for irrigation of field-grown melons by surface and subsurface drip irrigation. Isr J Plant Sci 59:159-169

Samie A, Obi L, Igumbor O, Momba B (2009) Focus on 14 sewage treatment plants in the Mpumalanga province, South Africa in order to gauge the efficiency of wastewater treatment. Afr Jf Microbiol Res 8:3276-3285

Shi Y, Gao L, Li W, Liu J, Cai Y (2012) Investigation of fluoroquinolones, sulfonamides and macrolides in long-term wastewater irrigation soil in Tianjin, China. Bull Environ Contam Toxicol $89: 857-861$

Siemens J, Huschek G, Siebe C, Kaupenjohann M (2008) Concentrations and mobility of human pharmaceuticals in the world's largest wastewater irrigation system, Mexico CityMezquital valley. Wat Res 42:2124-2134 
Sim W, Lee J, Lee E, Shin S, Hwang S, Oh J (2011) Occurrence and distribution of pharmaceutical in wastewater from households, livestock farms, hospitals and pharmaceutical manufactures. Chemosphere 82:179-186

Song Y, Wilke B, Song X, Gong P, Zhou Q, Yang G (2006) Polycyclic aromatics hydrocarbons (PAHs), polychlorinated biphenyls (PCBs) and heavy metals (HMs) as well as their genotoxicity in soil after long-term wastewater irrigation. Chemosphere 65:18591868

Sorensen S, Bailey M, Hansen L, Kroer N, Wuertz S (2005) Studying plasmid horizontal transfer in situ: a critical review. Nature 3:700-710

Sun K, Zhao Y, Gao B, Liu X, Zhang Z, Xing B (2009) Organochlorine pesticides and polybrominated diphenyl ethers in irrigated soils of Beijin, China: levels, inventory and fate. Chemosphere 77:1199-1205

Szczepanowski R, Linke B, Krhan I, Gartemann K, Gutzkow T, Eichler W, Puhler A, Schluter A (2009) Detection of 140 clinically relevant antibiotic-resistance genes in the plasmid metagenome of wastewater treatment plant bacteria showing reduced susceptibility to selected antibiotics. Microbiol 155:2306-2319

Tal A (2006) Seeking sustainability: Israel's evolving water management strategies. Science 313:1081-1084

Tarchitzky J, Lerner O, Shani U, Arye G, Lowengart-Aycicegi A, Brener A, Chen Y (2007) Water distribution pattern in treated wastewater irrigated soils: hydrophobicity effect. Eur J Soil Sci 58:573-588

Topp E, Monteiro S, Beck A, Coehlo B, Boxall A, Duenk P, Kleywegt S, Lapen D, Payne M, Sabourin L, Li H, Metcalfe C (2008) Runoff of pharmaceutical and personal care products following application of biosolid to an agricultural field. Sci Total Environ 369:52-59

Toze S (2006) Reuse of effluent water-benefits and risks. Agr Water Manage 80:140-159

Tree J, Adams M, Lees D (2003) Chlorination of indicator bacteria and viruses in primary sewage effluents. Appl Environ Microbiol 69:2038-2043

Truu M, Truu J, Heinsoo K (2009) Changes in soil microbial community under willow coppice: the effect of irrigation with secondarytreated municipal wastewater. Ecol Eng 35:1011-1020

Van Elsas J, Bailey M (2002) The ecology of transfer of mobile genetic elements. FEMS Microbiol Ecol 42:187-197
Van Meervenne E, Van Coillie E, Kerckhof M, Devlieghere F, Herman L, De Gelder S, Top M, Boon N (2012) Strain-specific transfer of antibiotic resistance from an environmental plasmid to foodborne pathogens. J Biomed Biotechnol. doi:10.1155/2012/834598

Verlicchi P, Aukidy M, Zambello E (2012) Occurrence of pharmaceutical compounds in urban wastewater: removal, mass load and environmental risk after a secondary treatment - a review. Sci Total Environ 429:123-155

Volkmann H, Schwartz T, Bischof P, Kirchen S, Obst U (2004) Detection of clinically relevant antibiotic-resistance genes in municipal wastewater using real-time PCR (TaqMan). J Microbiol Meth 56:277-286

Walker C, Watson J, Williams C (2012) Occurrence of carbamazepine in soils under different lands uses receiving wastewater. J Environ Qual 41:1263-1267

Wang Q, Cui Y, Liu X, Dong Y, Christie P (2006) Soil contamination and plant uptake of heavy metals at polluted sites in China. $\mathrm{J}$ Environ Sci Heal 38:823-838

Watkinson A, Murby E, Constanzo S (2007) Removal of antibiotics in conventional and advanced wastewater treatment: implications for environmental discharge and wastewater recycling. Water Res 41:4164-4176

Xi C, Zhang Y, Marrs C, Ye W, Simon C, Foxman B, Nriagu J (2009) Prevalence of antibiotic resistance in drinking water treatment and distribution systems. App Environ Ecol 75:5714-5718

Xu W, Zhang G, Li X, Zou S, Li P, Hu Z, Li J (2007) Occurrence and elimination of antibiotics at four sewage treatment plants in the Pearl River Delta (PRD), South China. Water Res 41:4526-4534

$\mathrm{Xu} \mathrm{J,} \mathrm{Wu} \mathrm{L,} \mathrm{Chen} \mathrm{W,} \mathrm{Jiang} \mathrm{P,} \mathrm{Chang} \mathrm{A} \mathrm{(2009a)} \mathrm{Pharmaceutical} \mathrm{and}$ personal care products (PPCPs) and endocrine disrupting compounds (EDCs) in runoff from a potato field irrigated with treated wastewater in southern California. J Health Sci 55:306-310

Xu J, Chen W, Wu L, Green R, Chang A (2009b) Leachability of some emerging contaminants in reclaimed municipal wastewaterirrigated turf grass fields. Environ Toxicol Chem 28:1842-1850

Zhang L, Liu Z (1989) A methodological research on environmental impact assessment of sewage irrigation region. Chi Environ Sci 9:298-303

Zhang Y, Marrs C, Simon C, Xi C (2009) Wastewater treatment contributes to selective increase of antibiotic resistance among Acinetobacter spp. Sci Total Environ 407:3702-3706 